\title{
Evaluation of Photomixotrophic Technique and Several Carbohydrate Sources as Affecting Banana Micropropagation
}

\author{
H.A. Emara ${ }^{1}$, A.A. Nower ${ }^{1}$, E.M. Hamza ${ }^{1 *}$ and F. El Shaib ${ }^{2}$ \\ ${ }^{1}$ Plant Biotechnology Department, Genetic Engineering and Biotechnology Research Institute \\ (GEBRI), University of Sadat City, Egypt \\ ${ }^{2}$ Horticulture Research Institute, Agriculture Research Center, Ministry of Agriculture and \\ ReclamationLland, Egypt \\ *Corresponding author
}

\section{A B S T R A C T}

Photomixotrophic technique refers to cell employment of endogenous and exogenous carbohydrate sources to obtain energy in the presence of $\mathrm{CO}_{2}$ enrichment. This investigation aimed to evaluate the photomixotrophic technique as a combination between

\begin{tabular}{|l|}
\hline Ke y w or d s \\
Photomixotrophic, \\
Carbon source, \\
Multiplication, Rooting, \\
Acclimatization, Banana \\
\hline Article Info \\
\hline Accepted: \\
06 September 2018 \\
Available Online: \\
10 October 2018 \\
\hline \hline
\end{tabular}
various concentrations of $\mathrm{CO}_{2}$ enrichment, and several types of carbohydrate sources (sucrose, fructose, glucose) at different concentrations on growth parameters of banana among all micropropagation stages. In multiplication, photomixotrophic technique enhanced the growth parameters, as the most effective carbohydrate was sucrose (20g/l with $600 \mathrm{ppm} \mathrm{CO}_{2}$ for shoot number and $10 \mathrm{~g} / \mathrm{l}$ with $900 \mathrm{ppm} \mathrm{CO}_{2}$ for shoot length), which may belong to its permeability through cell membrane and its gradually consumption. In rooting, presence of $\mathrm{CO}_{2}$ enrichment around the culture containers atmosphere may reduce the need of sucrose in culture medium to $1 \%$ instead of $3 \%$ (the most used in tissue culture medium). This result led to augment the vigor of the produced plantlets and configure them to tolerate the shock of acclimatization by enhancing photosynthesis and adjusting respiration and transpiration systems through activation of stomata functions and wax synthesis. In acclimatization, most growth parameters especially survival number and percentage were motivated by photomixotrophic at 900 or $1200 \mathrm{ppm} \mathrm{CO}_{2}$ and all sucrose concentrations. Indeed, photomixotrophic technique may decrease the exogenous need of carbohydrate with motivating the plant growth parameters of banana.

\section{Introduction}

Photomixotrophic is the micropropagation technique in which living organisms use endogenous and exogenous carbohydrates as a source of energy; degree of dependence considering the sugar concentration in the medium, with presence of feeding with $\mathrm{CO}_{2}$ in addition a higher photosynthetic photon flux
(PPF). Photomixotrophic enables the advertising of plantlet growth, a great survival percentage, and a descending of contamination (Nguyen et al., 2001 and Kozai, Kubota, 2005 and Nguyen et al., 2010). The $\mathrm{CO}_{2}$ enrichment can be obtained either by using a permeable gas filter(s) for vessel cap(s); which could be possessed by increasing concentration of $\mathrm{CO}_{2}$ around the cultivation vessels, or by supply of 
$\mathrm{CO}_{2}$ directly into the vessels, i.e., by forced ventilation. Different responses of growth parameters were observed as a result of increasing $\mathrm{CO}_{2}$ concentration in individual plant species and at different ontogenetic stages (Figueira et al., 1991; Fournioux and Bessis, 1993), and interactions with other environmental factors, especially PPF and medium composition, have to be concerned (Kozai and Iwanami, 1988; Kozai et al., 1988a, b; Kirdmanee et al., 1995; Sallanon et al., 1995; Du“ ring and Harst, 1996; Seko and Nishimura, 1996; and Seko and Kozai, 1997). In vitro growth of many species of plant can be promoted by increasing the $\mathrm{CO}_{2}$ concentration and light intensity, which decreasing the relative humidity of the vessel and lead to activate stomata and wax formation (Xiao et al., 2011). The best growth and development of Philodendron scandens during acclimatization stage were recorded for plantlets produced under light intensity at 1000 LUX with modified aeration during rooting stage in vitro and acclimatized under light intensity at 4000 LUX ex vitro (Dahab et al., 2000). Using forced $\mathrm{CO}_{2}$ ventilated vessels with a low concentration of sucrose could successfully enhancement a photomixotrophic culture, which gave healthy plantlets with higher leaf dry weight and welldeveloped leaves of plantlets. Also, low concentration of sucrose in ventilated vessels was facilitated the acclimatization of plantlets because of formation of rooting system began to develop causing efficient use of water (Zobayed et al., 2001; Zobayed et al., 2004; Hassankhah et al., 2014; and Pérez et al., 2015). Photomixotrophic conditions was more efficient than photoautotrophic in growth parameters; plant height, nods number, leaves number, leaf area, dry weight, and multiplication efficiency (Kozai and Iwanami, 1988; Khan et al., 2002; Badr et al., 2011; Sekeli et al., 2013; Shin et al., 2013 and Teixeira da Silva et al., 2017).
The growth and multiplication of shoots in vitro are affected by many factors, one of them is the carbon source types which considered main component of the medium (Emara et al., 2017). The role of carbon sources may be as a source of energy and osmotic agents to promote the growth of plant tissues. There are several opinions on the beneficial effects of various carbon sources (sucrose, glucose fructose, etc.) on the growth parameters of plants in vitro. Actually, sucrose is the most performed carbohydrate source in the tissue culture studies because of its high efficient uptake through the plasma membrane of plant cell (Morfeine, 2014). On contrary, sucrose may suppress photosynthesis because sucrose saves sufficient energy, which needed to metabolic activities. Also, sucrose plays a role in the mechanism mediating control of the regulation decreasing photosynthesis (Rolland et al., 2002; Amiard et al., 2005; Franck et al., 2006 and Jo et al., 2009). In photomixotrophic, sucrose increased the culture medium osmotic potential, so, it is difficult to up take water for plants in vitro, for this reason, transpiration rate was lower (Pérez et al., 2015).

The aim work was to evaluate photomixotrophic culture technique in presence of different concentrations of carbon sources (sucrose, fructose and glucose) as affecting growth parameters of micropropagated banana.

\section{Materials and Methods}

\section{Establishment stage}

\section{Plant materials}

Banana (Musa acuminate) cultivar Grand Naine growing in the field at Berkash, Giza Governorate. Healthy, true to type and free disease symptoms. Suckers were carefully selected from mother plants, which are 
characterized as a high fruit quality background and externally yield. Suckers were shortened to $20 \mathrm{~cm}$ in length and transferred directly to the tissue culture laboratory.

\section{Sterilization of plant materials}

Explants were prepared and sterilized as described by Hamza, 2013. Explants were reach a height of $1.0 \mathrm{~cm}$ and $1.2 \mathrm{~cm}$ in diameter before cultured on the medium.

\section{Culture medium}

Basal medium (Murashige and Skoog, 1962 (MS) supplemented with $3.0 \mathrm{mg} / \mathrm{l}$ benzyl adenine (BAP), $30 \mathrm{~g} / \mathrm{l}$ sucrose, and agar as solidified agent $(5.5 \mathrm{~g} / \mathrm{l})$. The $\mathrm{pH}$ of the medium was adjusted to $5.7 \pm 0.2$ with $(0.1 \mathrm{M})$ $\mathrm{KOH}$ or $(0.1 \mathrm{M}) \mathrm{HCl}$ prior to addition the gelling agent. Media were distributed in jars $(350 \mathrm{ml})$, each jar contained $50 \mathrm{ml}$ of medium and capped with white polypropylene closure, then medium was sterilized in autoclave at $121^{\circ} \mathrm{C}$ and $1.1 \mathrm{Kg} / \mathrm{cm}^{2}$ for $20 \mathrm{~min}$ as recommended by with minor modification.

\section{Culture of explant}

Shoot tips were aseptically cultured and incubated in a total darkness at $25 \pm 1^{\circ} \mathrm{C}$ and were re-cultured twice at 3 weeks intervals on the same medium composition.

\section{Multiplication stage}

Shoot tips; which were vital and free of contamination from the previous stage, were recultured until reach to shoot mulplication Then, cultures were transferred to the growth room at $27 \pm 1^{\circ} \mathrm{C}$ under light conditions and exposed to a $16 / 8 \mathrm{~h}$. photoperiod (light/dark) using ordinary fluorescent tubes with a light intensity of 2000 Lux. These explants were used in the next step of bud proliferation. After six subcultures on the same medium and under same incubation conditions, the investigations were implemented.

\section{Preparation of photomixotrophic system}

Various concentrations of $\mathrm{CO}_{2}$ enrichment $(0.0,600,900$ and $1200 \mathrm{ppm})$ were saved around the culture jars environment which incubated in transparent sealing boxes. Culture jars were save $\mathrm{CO}_{2}$ concentrations (by using $\mathrm{CO}_{2}$ generation sachets) through employ permeable membrane that allow gas exchange as described in the following steps:

\section{Preparing boxes}

To configure enrichment $\mathrm{CO}_{2}$ in the environment around the culture jars, clear transparent polyethylene boxes; which were 17 liters in volume, were completely sealed $\begin{array}{llll}\text { cap to save } & \mathrm{CO}_{2} & \text { enrichment }\end{array}$ (photomixotrophic) around culture jars (Photo 1A).

\section{Preparing culture jars}

The caps of culture jars (350ml jars) were modified by making circular pore $1.3 \mathrm{~cm}$ diameter and these pores were covered with a cellulose nitrate membrane (provided by Sartorius AG company, Landstresse 94-108 $37075 \quad$ Goettingen, Germany WWW.sartorius.com), where cellulose nitrate membrane allow gas exchange between internal and external culture jars which were incubated separately in boxes vessel to save need of concentration of $\mathrm{CO}_{2}$ enrichment in boxes environment (Nguyen et al., 2010) (Photo 1B and C).

\section{Save $\mathrm{CO}_{2}$ concentrations}

Culture jars were incubated in sealed vessels, which save determined $\mathrm{CO}_{2}$ concentrations around culture jars through $\mathrm{CO}_{2}$ generation sachets (AnaeroGen ${ }^{\mathrm{TM}}$ 2.5L which, 
manufactured for Oxoid Ltd by Mitsubishi Gas Chemical Company Inc. Japan. WWW.thermofisher.com).

Evaluation of photomixotrophic and various concentrations of several carbohydrate types as affecting banana growth parameters during multiplication stage

The investigation aimed to evaluate photomixotrophic of banana cultivar Grande Naine through examine the effect of three concentrations $(10,20$ and $30 \mathrm{~g} / \mathrm{l})$ of several types of carbohydrate sources (sucrose, fructose, glucose) individual and combined with four concentrations of $\mathrm{CO}_{2}$ enrichment $(0,600,900$ and $1200 \mathrm{ppm})$. Culture jars were incubated in sealed boxes after putting the $\mathrm{CO}_{2}$ generation sheet in boxes to save the $\mathrm{CO}_{2}$ concentration. Boxes were incubated at $27 \pm 1^{\circ} \mathrm{C}$ under light conditions and $16 / 8 \mathrm{~h}$ (light/dark) as photoperiod with 2000 Lux light intensity. The experiment maintained for two subcultures with 21days intervals under photomixotrophic, then, shoots number/explant, number of leaves/explant; which determined by numerate all leaves produced in the culture jars which depended on the number of regenerated shoots, leaves number/shoot, shoot length $(\mathrm{cm})$ and leaf area $\left(\mathrm{cm}^{2}\right)$ were recorded.

Evaluation of photomixotrophic and various concentrations of several carbohydrate types as affecting banana growth parameters during rooting and acclimatization stages

Shoots which produced in multiplication stage were transferred to rooting medium recommended by Ibrahim et al., (2006) which consisted of MS medium instituted with $2 \mathrm{mg} / \mathrm{l}$ IBA (indole-3-butyric acid), 1.5g/l activated charcoal, $0.6 \%$ Phyto agar as solidification agent and different concentrations of sucrose
(10, 20 and $30 \mathrm{~g} / \mathrm{l})$. Each treatment of sucrose was incubated under different $\mathrm{CO}_{2}$ enrichment conditions $(0,600,900$ and $1200 \mathrm{ppm})$ and light intensity 3000lux (recommended by Ibrahim et al., 2006). Each treatment contained 10culture jars and each jar contained 10shoots. After one month, root number, root length $(\mathrm{cm})$, plantlet height $(\mathrm{cm})$, pseudo stem length $(\mathrm{cm})$, pseudo stem diameter $(\mathrm{mm})$, number of leaves/plantlet, leaf area $\left(\mathrm{cm}^{2}\right)$ and plantlet fresh weight $(\mathrm{g})$ were recorded. The resulted plantlets were washed under running tap water and rinsed in antifungal solution for $2 \mathrm{~min}$ then planted in $5 \mathrm{~cm}$ pots full with cultured medium consisted of $1: 1: 1 \mathrm{v} / \mathrm{v}$ peatmoss: sand : vermiculite, well watered and caped with polyethylene bags and transferred into greenhouse. Polyethylene bags were gradually removed. Survival plantlets number was recorded, and survival percentage was calculated after one month.

\section{Statistical analysis}

Each treatment contained ten culture jars as replicates (each jar contained one explant in multiplication experiments while ten shoots in rooting ones, where average values were calculated to determined replicate value). All experiments were arranged in completely randomized design SAS Institute (2002). Differences among the various treatments were compared using LSD test at 5\% according to according to Steel and Torrie (1980). M-state free computer program was used for analysis.

\section{Results and Discussion}

Evaluation of photomixotrophic technique and different concentrations of sugar types as affecting banana plant parameters during multiplication stage

The effect of different concentrations of three types of sugar (sucrose, fructose and glucose) 
combined with four levels of $\mathrm{CO}_{2}$ concentrations (enrichment $\mathrm{CO}_{2}$ photomixotrophic technique) was investigated for in vitro regeneration of banana variety Grand Naine on multiplication. Responses recorded as the differences in nature of morphogenetic response; i.e., number of shoots, number of leaves, shoot length and leaf area.

Evaluation of photomixotrophic technique and different concentrations of sugar types as affecting banana plant parameters

Presence of $\mathrm{CO}_{2}$ enrichment in the vessel atmosphere increased the number of shoots, the highest value of number of shoots resulted from (600 ppm $\mathrm{CO}_{2}$ ), while, the lowest number of shoots value observed on $900 \mathrm{ppm}$ $\mathrm{CO}_{2}$ (Fig. 1). There was no significant difference between 900, $1200 \mathrm{ppm} \mathrm{CO}_{2}$ and control. Concerning the effect of different concentrations of several types of sugar, results indicated that the significant highest number of shoots was obtained when MS medium was containing $20 \mathrm{~g} / \mathrm{l}$ sucrose $(10.83$ shoots/explant), followed by MS medium containing $10 \mathrm{~g} / \mathrm{l}$ sucrose, $20 \mathrm{~g} / \mathrm{l}$ fructose or $10 \mathrm{~g} / \mathrm{l}$ glucose $(7.58, \quad 6.00$ and 6.00 shoots/explant, respectively) with no significant differences between them. Concerning the combination between enrichment $\mathrm{CO}_{2}$ photomixotrophic technique and different concentrations of sugar types, MS medium supplemented with $20 \mathrm{~g} / \mathrm{l}$ sucrose $+600 \mathrm{ppm} \mathrm{CO}_{2}$ significantly gave the highest value of number of shoots (13.33 shoots/explant), followed by MS medium containing $10 \mathrm{~g} / \mathrm{l}$ sucrose $+600 \mathrm{ppm} \mathrm{CO}_{2}$, MS medium containing $20 \mathrm{~g} / \mathrm{l}$ sucrose $+900 \mathrm{ppm}$ $\mathrm{CO}_{2}$ or MS medium containing $20 \mathrm{~g} / \mathrm{l}$ sucrose $+1200 \mathrm{ppm} \mathrm{CO}_{2}$ (10.67, 10.67 or 10.33 shoots/explant, respectively), with no significant difference between them (Fig. 1). It is important to refer that all sugar treatments, which did not expose to enrichment $\mathrm{CO}_{2}$ photomixotrophic resulted in producing low shoot proliferation, comparing with exposed ones, which reflect the enhancement effect of enrichment $\mathrm{CO}_{2}$ photomixotrophic technique.

$\mathrm{CO}_{2}$ enrichment in the vessel atmosphere (photomixotrophic technic) enhanced banana shoot length significantly, data in Figure 1 show that $\mathrm{CO}_{2}$ enrichment in the vessel atmosphere at concentration $900 \mathrm{ppm}$ resulted in the highest value of shoot length $(4.57 \mathrm{~cm})$ followed by $\mathrm{CO}_{2}$ enrichment in the vessel atmosphere at concentration 1200 and 600ppm $(4.47$ and $3.95 \mathrm{~cm}$, respectively) with no significant differences between them. While, free $\mathrm{CO} 2$ atmosphere (control) produced the significant lowest value of shoot length $(2.96 \mathrm{~cm})$. Concerning the concentrations of sugar types, the medium containing $10 \mathrm{~g} / \mathrm{l}$ glucose, $10 \mathrm{~g} / \mathrm{l}$ sucrose, $20 \mathrm{~g} / \mathrm{l}$ sucrose or $20 \mathrm{~g} / \mathrm{l}$ glucose maximized shoot length of banana with no significant differences between them (6.01, 5.75, 5.67 or $4.33 \mathrm{~cm}$, respectively). Regarding the combination between enrichment $\mathrm{CO}_{2}$ photomixotrophic technique and different concentrations of sugar types, MS medium supplemented with 10 or $20 \mathrm{~g} / \mathrm{l}$ sucrose and $\mathrm{CO}_{2}$ enrichment at all concentration considerably positive affected banana shoot length, anyway, the highest shoot length observed on MS supplemented with $10 \mathrm{~g} / \mathrm{l}$ sucrose and $900 \mathrm{ppm}$ enrichment $\mathrm{CO}_{2}(7.50 \mathrm{~cm})$.

Also, all $\mathrm{CO}_{2}$ enrichment treatments positively affected number of leaves compared with nonenrichment $\mathrm{CO}_{2}$ vessels (control treatment) (Fig. 2). The highest number of leaves/explant and the highest number of leaves/shoot (21.85 and 4.6 leaves, respectively) were observed when $\mathrm{CO}_{2}$ enrichment concentration in the vessel atmosphere was $1200 \mathrm{ppm}$, while, nonenrichment $\mathrm{CO}_{2}$ vessel gave the significant lowest value (12.89 leaves/explant) and $\mathrm{CO}_{2}$ enrichment at concentration $600 \mathrm{ppm}$ gave the lowest leaves number/shoot, because of the 
highest number of shoots in this treatment. Concerning concentrations of sugar types, generated shoots on MS media containing (10 or $20 \mathrm{~g} / \mathrm{l}$ sucrose resulted in maximum number of leaves, but shoots grown on media containing fructose or glucose reduced the same parameter.

Considering the combination between $\mathrm{CO}_{2}$ enrichment concentrations in the vessel atmosphere treatments and concentrations of sugar types, the highest value of number of leaves/explant resulted from MS supplemented with $20 \mathrm{~g} / 1$ sucrose in presence of 600,900 or $1200 \mathrm{ppm} \mathrm{CO}_{2}$ in the vessel around culture jars with no significant difference between these treatments (43.00, 39.33 and 36.33 leaves/explant, respectively) while, non-enrichment $\mathrm{CO}_{2}$ (control) produced the highest number of leaves/shoot, these results may attribute to the enhancement ability of $\mathrm{CO}_{2}$ enrichment to produce high number of shoots which negatively affected the number of leaves/shoot but enhance the number of leaves/ explant.

Also, leaf area was augmented in presence of all $\mathrm{CO}_{2}$ enrichment vessels treatments comparing with non-enrichment $\mathrm{CO}_{2}$ vessels (control treatment) which produced the smallest leaf area (Fig. 3).

Concerning the effect of different concentrations of sugar types, MS medium supplied with 10 or $20 \mathrm{~g} / \mathrm{l}$ sucrose and MS medium supplied with $10 \mathrm{~g} / \mathrm{l}$ glucose resulted in the highest leaf area, it is important to refer that sucrose treatments are the effective treatments more than glucose because it produced high leaf area and high number of leaves, while glucose produced high leaf area but the lowest number of leaves. Results indicated that the combination between $\mathrm{CO}_{2}$ enrichment concentrations in the vessel atmosphere treatments and concentrations of sugar types produced the largest leaf area when $\mathrm{CO}_{2}$ enrichment concentration was 900 or $1200 \mathrm{ppm}$ around culture vessel and MS medium supplemented with $10 \mathrm{~g} / \mathrm{l}$ sucrose (7.50 and $7.17 \mathrm{~cm} 2$, respectively), no significant differences were detected between two treatments (Fig. 3 and Photo 2).

Evaluation of photomixotrophic technique and different concentrations of sugar types as affecting banana plant parameters during rooting stage

Analysis data of growth parameters during multiplication stage indicated the priority of sucrose as a source of carbohydrate when compared with either glucose or fructose, so, it is selected to be the source of carbohydrate during rooting stage. Determination the most effective concentrations of sucrose in presence of different concentrations of $\mathrm{CO}_{2}$ enrichment (as photomixotrophic technique) during rooting stage is the aim of this investigation, results depended on the response of plantlet growth parameters; i.e., number of roots, root length, plantlet height, pseudo stem length and diameter, number of leaves, leaf area and plantlet fresh weight. Results in Table 1 revealed that number of roots did not significantly affected by all sucrose concentrations, while, concentrations of $\mathrm{CO}_{2}$ enrichment (as photomixotrophic technique) cleared significant positive responses of number of roots.

It is clear that, all concentrations of $\mathrm{CO}_{2}$ enrichment (as photomixotrophic technique) in combined with all sucrose concentrations were significant superior on all free $\mathrm{CO}_{2}$ treatments, no significant difference was recorded between all $\mathrm{CO}_{2}$ enrichment treatments, the highest roots number recorded when MS instituted with $10 \mathrm{~g} / 1$ sucrose in combined with 600,900 or $1200 \mathrm{ppm} \mathrm{CO}_{2}$. Concerning the root length, data indicated that no significant differences were recorded between all sucrose concentrations. 
Concentrations of $\mathrm{CO}_{2}$ enrichment (as photomixotrophic technique) augmented root length significantly when compared with free $\mathrm{CO}_{2}$ treatments. The tallest roots were obtained from MS supplemented with 10, 20 or $30 \mathrm{~g} / \mathrm{l}$ sucrose with presence of 900 or 1200ppm $\mathrm{CO}_{2}$ enrichment. Data in Table 2 and Figure 4 indicated that increasing sucrose concentration lead to enhance plantlet length, the highest plantlet length $(10.33 \mathrm{~cm})$ recorded when MS medium supplemented with $30 \mathrm{~g} / \mathrm{l}$ sucrose.

Concerning concentrations of $\mathrm{CO}_{2}$ enrichment, the highest plantlet length $(9.8 \mathrm{~cm})$ resulted from $1200 \mathrm{ppm} \mathrm{CO}_{2}$.

Considering the interaction between sucrose concentrations and concentrations of $\mathrm{CO}_{2}$ enrichment, most concentrations of $\mathrm{CO}_{2}$ enrichment enhanced plantlet length in combination with MS medium supplemented with 10 or $30 \mathrm{~g} / \mathrm{l}$ sucrose, indeed, the highest plantlet length $(11.5 \mathrm{~cm})$ resulted from MS medium supplemented with $30 \mathrm{~g} / \mathrm{l}$ sucrose in presence of $1200 \mathrm{ppm} \mathrm{CO}_{2}$.

The same results were detected for pseudo stem length. On the other hand, pseudo stem diameters showed non-significant differences between all examined concentrations of sucrose.

While, increasing concentrations of $\mathrm{CO}_{2}$ enrichment led to significantly maximize the values of pseudostem diameters. Inter action between sucrose concentrations and concentrations of $\mathrm{CO}_{2}$ enrichment revealed that increasing presence of $\mathrm{CO}_{2}$ around culture vessels significantly enhanced pseudostem diameter with all sucrose concentrations.

It is important to mention that no significant differences were observed between all sucrose concentrations when $\mathrm{CO}_{2}$ concentration were
900 or $1200 \mathrm{ppm}$, these results refer to the ability of adding $10 \mathrm{~g} / \mathrm{l}$ sucrose instead of $30 \mathrm{~g} / \mathrm{l}$ sucrose to the medium in presence of 900 or $1200 \mathrm{ppm} \mathrm{CO} \mathrm{CO}_{2}$ around the culture vessels.

Concerning number of leaves/plantlet, data in Table 3 and Photo 3 indicated that sucrose concentration relatively affected number of leaves but there were no significant differences between all sucrose concentrations. Concentrations of $\mathrm{CO}_{2}$ positively affected number of leaves and significant differences appeared between $\mathrm{CO}_{2}$ enrichment vessels and free- $\mathrm{CO}_{2}$ ones (control).

Interaction data cleared the priority of MS medium supplemented with $10 \mathrm{~g} / \mathrm{l}$ sucrose in presence of 900 or $1200 \mathrm{ppm} \mathrm{CO}_{2}$, also, MS medium supplemented with 20 or $30 \mathrm{~g} / \mathrm{l}$ sucrose in presence of all $\mathrm{CO}_{2}$ concentrations cleared significant priority in number of leaves.

In the other hand, leaf area was significantly augmented with increasing sucrose concentration in medium. While, no significant difference was observed between all $\mathrm{CO}_{2}$ enrichment concentrations and free$\mathrm{CO}_{2}$ vessels (control). Interaction data cleared that all sucrose concentration in presence of 900 or $1200 \quad \mathrm{ppm} \quad \mathrm{CO}_{2}$ resulted in augmentation leaf area but with no significant difference between these treatments and $30 \mathrm{~g} / \mathrm{l}$ sucrose free- $\mathrm{CO}_{2}$.

Indeed, this result should be considered the number of leaves for each treatment, and the priority of all $\mathrm{CO}_{2}$ enrichment vessel in number of leaves, which mean significant priority in the total leaves area per plantlet, which may affect the ability of these plantlets to do efficient photosynthesis and high recovery and survival percent in acclimatization. 
Table.1 Evaluation of photomixotrophic technique and different concentrations of sugar types as affecting banana plant parameters during rooting stage

\begin{tabular}{|c|c|c|c|c|c|c|c|c|c|c|}
\hline \multirow{3}{*}{ 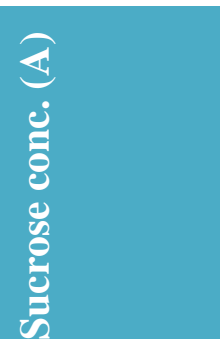 } & \multicolumn{5}{|c|}{ Number of roots/ plantlet } & \multicolumn{5}{|c|}{ Root length (cm) } \\
\hline & \multicolumn{10}{|c|}{$\mathrm{CO}_{2}$ enrichment concentrations (ppm) (B) } \\
\hline & 0.0 & 600 & 900 & 1200 & $\begin{array}{c}\text { Mean } \\
\text { (A) }\end{array}$ & $\mathbf{0 . 0}$ & 600 & 900 & 1200 & $\begin{array}{c}\text { Mean } \\
\text { (A) }\end{array}$ \\
\hline $10 \mathrm{~g} / 1$ & 6.0 & 9.5 & 10.00 & 11.8 & 7.9 & 3.3 & 6.6 & 7.4 & 7.5 & 6.2 \\
\hline $20 \mathrm{~g} / \mathrm{l}$ & 6.5 & 8.6 & 10.30 & 12.5 & 7.9 & 5.0 & 6.6 & 7.7 & 7.6 & 6.8 \\
\hline $30 \mathrm{~g} / 1$ & 7.3 & 9.8 & 11.25 & 11.6 & 9.2 & 5.9 & 6.4 & 7.8 & 7.1 & 6.8 \\
\hline Mean (B) & 6.20 & 8.4 & 8.8 & 11.3 & & 4.7 & 6.5 & 7.6 & 7.4 & \\
\hline $\begin{array}{c}\text { LSD:5\% A } \\
\text { B } \\
\text { AxB }\end{array}$ & \multicolumn{5}{|c|}{$\begin{array}{l}\text { NS } \\
1.4 \\
4.3\end{array}$} & & & $\begin{array}{l}\text { NS } \\
1.3 \\
2.3\end{array}$ & & \\
\hline
\end{tabular}

Table.2 Effect of photomixotrophic and different concentrations of sucrose on growth parameters of banana cultivar Grande Naine during rooting stage

\begin{tabular}{|c|c|c|c|c|c|c|c|c|c|c|c|c|c|c|c|}
\hline \multirow{3}{*}{ 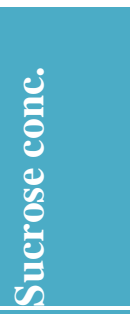 } & \multicolumn{5}{|c|}{ Plantlet height (cm) } & \multicolumn{5}{|c|}{ Pseudostem length $(\mathrm{cm})$} & \multicolumn{5}{|c|}{ Pseudostem diameter (mm) } \\
\hline & \multicolumn{15}{|c|}{$\mathrm{CO}_{2}$ enrichment concentrations (ppm) } \\
\hline & 0.0 & 600 & 900 & $\begin{array}{c}120 \\
0\end{array}$ & $\begin{array}{l}\text { Me } \\
\text { an } \\
(\mathrm{A})\end{array}$ & $\mathbf{0 . 0}$ & 600 & 900 & $\begin{array}{c}120 \\
0\end{array}$ & $\begin{array}{l}\text { Me } \\
\text { an } \\
\text { (A) }\end{array}$ & $\mathbf{0 . 0}$ & 600 & 900 & $\begin{array}{c}120 \\
0\end{array}$ & $\begin{array}{l}\text { Me } \\
\text { an } \\
\text { (A) }\end{array}$ \\
\hline $10 \mathrm{~g} \backslash \mathrm{L}$ & 6.3 & 7.0 & 7.7 & 9.8 & 7.7 & 3.2 & 4.5 & 4.5 & 4.7 & 4.2 & $\begin{array}{l}4.5 \\
0\end{array}$ & $\begin{array}{l}4.5 \\
0\end{array}$ & 6.8 & $\begin{array}{l}7.5 \\
0\end{array}$ & $\begin{array}{l}5.8 \\
4\end{array}$ \\
\hline $20 \mathrm{glL}$ & 9.8 & 8.3 & 9.8 & 8.2 & 8.3 & 4.2 & 4.6 & 5.0 & 4.7 & 4.5 & $\begin{array}{l}5.0 \\
0\end{array}$ & $\begin{array}{l}6.5 \\
0\end{array}$ & $\begin{array}{l}6.7 \\
0\end{array}$ & $\begin{array}{l}7.3 \\
0\end{array}$ & $\begin{array}{l}6.4 \\
0\end{array}$ \\
\hline $30 \mathrm{~g} \backslash \mathrm{L}$ & $\begin{array}{c}10 . \\
5\end{array}$ & 8.0 & $\begin{array}{c}10 . \\
3\end{array}$ & $\begin{array}{c}11 . \\
5\end{array}$ & 10.3 & 4.5 & 4.6 & 4.3 & 5.2 & 4.8 & $\begin{array}{l}5.1 \\
7\end{array}$ & $\begin{array}{l}6.6 \\
0\end{array}$ & $\begin{array}{l}6.8 \\
3\end{array}$ & $\begin{array}{l}7.5 \\
6\end{array}$ & $\begin{array}{l}6.5 \\
3\end{array}$ \\
\hline $\begin{array}{c}\text { Mean } \\
\text { (B) }\end{array}$ & 8.9 & 6.8 & 9.3 & 9.8 & & 3.4 & 4.6 & 4.6 & $\mathbf{4 . 0}$ & & $\begin{array}{l}4.8 \\
9\end{array}$ & $\begin{array}{l}5.8 \\
7\end{array}$ & $\begin{array}{l}6.7 \\
7\end{array}$ & $\begin{array}{l}7.4 \\
5\end{array}$ & \\
\hline $\begin{array}{c}\text { LSD at } \\
5 \% \text { A } \\
\text { B } \\
\text { AxB }\end{array}$ & & & $\begin{array}{l}0.7 \\
0.6 \\
1.2\end{array}$ & & & & & $\begin{array}{l}0.4 \\
0.4 \\
0.8\end{array}$ & & & & & $\begin{array}{l}0.99 \\
0.86 \\
1.71\end{array}$ & & \\
\hline
\end{tabular}


Table.3 Effect of photomixotrophic and different concentrations of sucrose plantlet growth parameters of banana cultivar Grande Naine during rooting stage

\begin{tabular}{|c|c|c|c|c|c|c|c|c|c|c|}
\hline \multirow{3}{*}{ 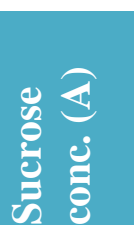 } & \multicolumn{5}{|c|}{ Number of leaves/ plantlet } & \multicolumn{5}{|c|}{ Leaf area $\left(\mathrm{cm}^{2}\right)$} \\
\hline & \multicolumn{10}{|c|}{$\mathrm{CO}_{2}$ enrichment concentrations (ppm) (B) } \\
\hline & 0.0 & 600 & 900 & 1200 & $\begin{array}{l}\text { Mean } \\
\text { (A) }\end{array}$ & $\mathbf{0 . 0}$ & 600 & 900 & 1200 & $\begin{array}{c}\text { Mean } \\
\text { (A) }\end{array}$ \\
\hline $10 \mathrm{~g} / \mathrm{l}$ & 6.0 & 6.9 & 8.0 & 10.8 & 7.9 & 3.3 & 4.6 & 5.4 & 7.5 & 5.2 \\
\hline $20 \mathrm{~g} / \mathrm{l}$ & 4.5 & 8.5 & 9.3 & 9.5 & 7.9 & 5.0 & 4.6 & 6.7 & 4.6 & 4.9 \\
\hline $30 \mathrm{~g} / 1$ & 7.3 & 9.8 & 9.1 & 10.6 & 9.2 & 7.9 & 5.4 & 5.8 & 7.1 & 6.6 \\
\hline $\begin{array}{c}\text { Mean } \\
\text { (B) }\end{array}$ & 5.9 & 8.4 & 8.8 & 10.3 & & 5.4 & 4.4 & 5.9 & 6.4 & \\
\hline \multicolumn{2}{|c|}{$\begin{array}{c}\text { LSD at 5\% level A } \\
\text { B }\end{array}$} & & & & & & & $\begin{array}{l}1.2 \\
1.1 \\
2.2\end{array}$ & & \\
\hline
\end{tabular}

Table.4 Effect of photomixotrophic and different concentrations of sucrose on plantlet weight of banana cultivar Grande Naine during rooting stage

\begin{tabular}{|c|c|c|c|c|c|}
\hline \multirow[t]{2}{*}{ Sucrose conc. (A) } & \multicolumn{4}{|c|}{$\mathrm{CO}_{2}$ enrichment concentrations (ppm) (B) } & \multirow[t]{2}{*}{ Mean (A) } \\
\hline & 0.0 & 600 & 900 & 1200 & \\
\hline $10 \mathrm{~g} / 1$ & 1.7 & 2.5 & 2.8 & 4.4 & 2.9 \\
\hline $20 \mathrm{~g} / 1$ & 2.4 & 2.8 & 3.1 & 4.6 & 3.2 \\
\hline $30 \mathrm{~g} / 1$ & 2.8 & 3.7 & 3.9 & 5.1 & 3.8 \\
\hline Mean (B) & 2.3 & 3.0 & 3.3 & 4.7 & \\
\hline LSD at $5 \%$ level $\mathbf{A}$ & \multicolumn{5}{|c|}{0.8} \\
\hline $\mathbf{B}$ & \multicolumn{5}{|c|}{0.7} \\
\hline $\mathbf{A x B}$ & \multicolumn{5}{|c|}{1.4} \\
\hline
\end{tabular}

Table.5 Effect of photomixotrophic technique under different concentrations of sucrose on plantlet survival number $(\%)$ of banana cultivar Grande Naine after acclimatization stage

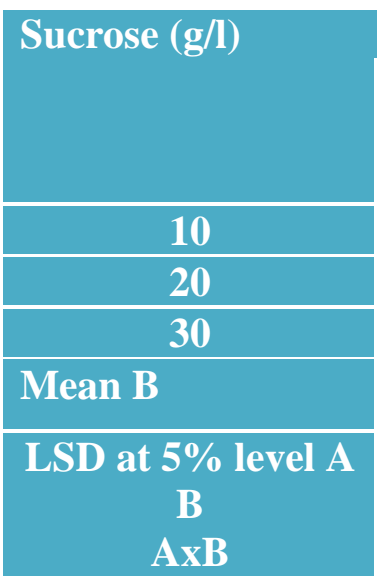

\begin{tabular}{|c|c|c|c|c|}
\hline \multicolumn{5}{|c|}{ Number of survive plantlets (\% of survival) } \\
\hline \multicolumn{5}{|c|}{$\mathrm{CO}_{2}$ concentration $(\mathrm{ppm})$} \\
\hline Control & 600 & 900 & 1200 & Mean A \\
\hline $7.7(70.0)$ & $9.5(86.4)$ & $10.4(94.5)$ & $11.0(100.0)$ & $10.0(90.9)$ \\
\hline $7.8(70.9)$ & $10.8(98.2)$ & $10.9(99.1)$ & $10.6(96.4)$ & $10.0(90.9)$ \\
\hline $9.2(83.6)$ & $10.8(98.2)$ & $10.9(99.1)$ & $10.9(99.1)$ & $10.5(95.5)$ \\
\hline $8.3(75.5)$ & $10.2(92.7)$ & $10.7(97.3)$ & $10.8(98.2)$ & \\
\hline & & $\begin{array}{l}\text { NS } \\
0.9 \\
1.7\end{array}$ & & \\
\hline
\end{tabular}


Fig.1 Effect of enrichment $\mathrm{CO}_{2}$ photomixotrophic technique and different concentrations of sugar types on shoots number/explant and shoot length $(\mathrm{cm})$ during multiplication stage

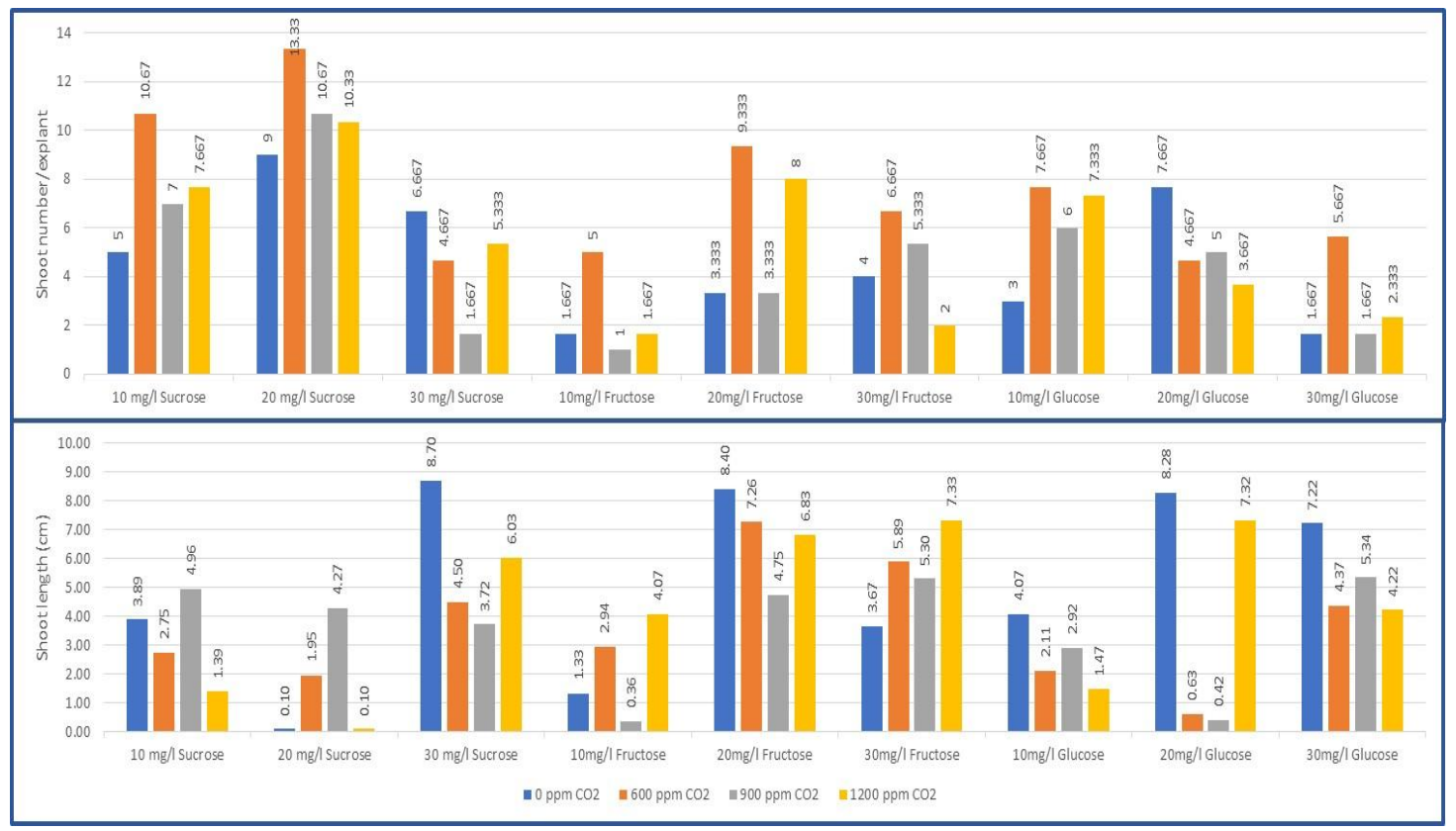

Fig.2 Effect of enrichment $\mathrm{CO}_{2}$ photomixotrophic technique and different concentrations of sugar types on leaves number/shoot and leaves number/explant during multiplication stage

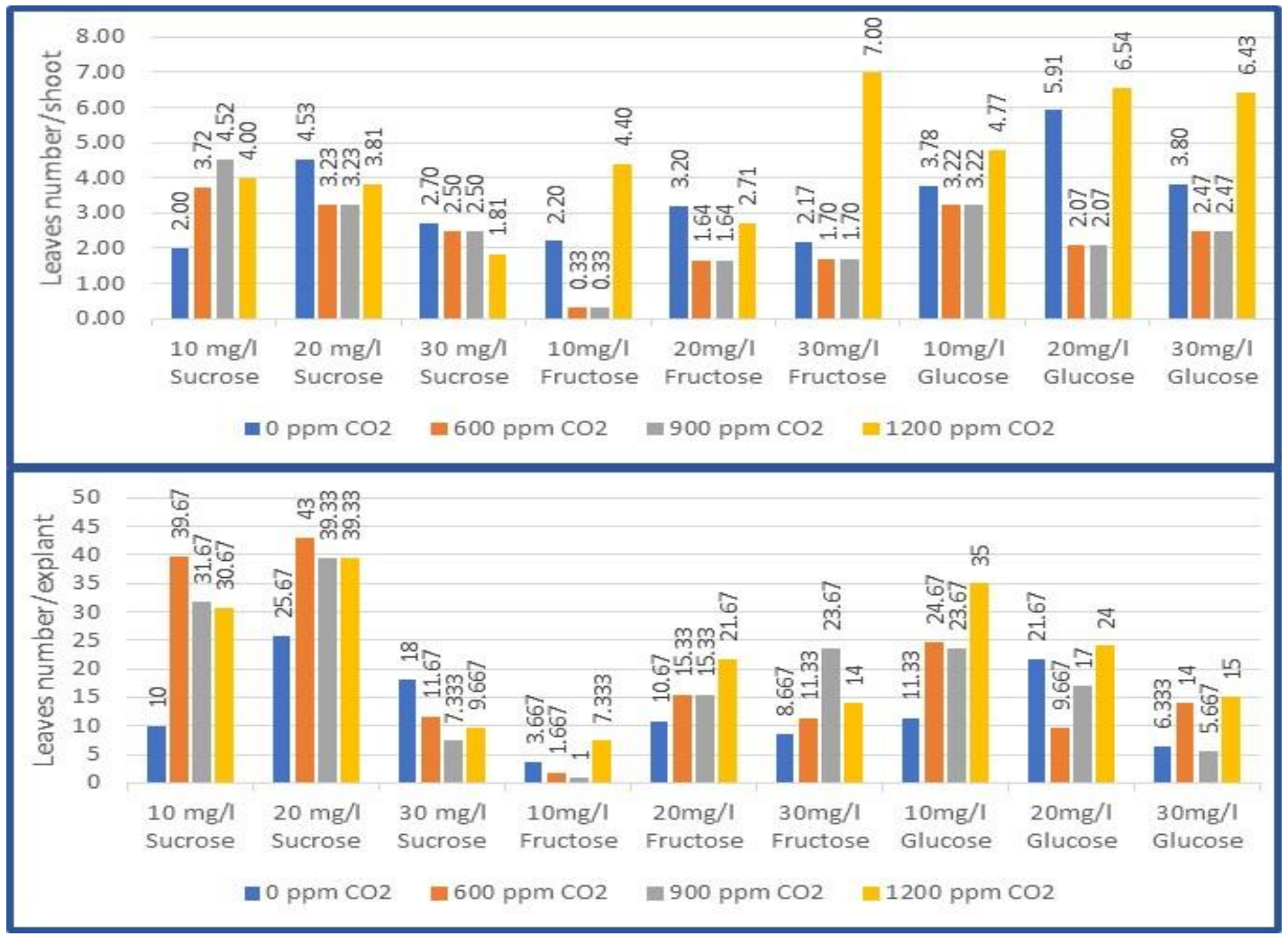


Fig.3 Effect of photomixotrophic technique and different concentrations of sugar types on leaf area $\left(\mathrm{cm}^{2}\right)$ during multiplication stage

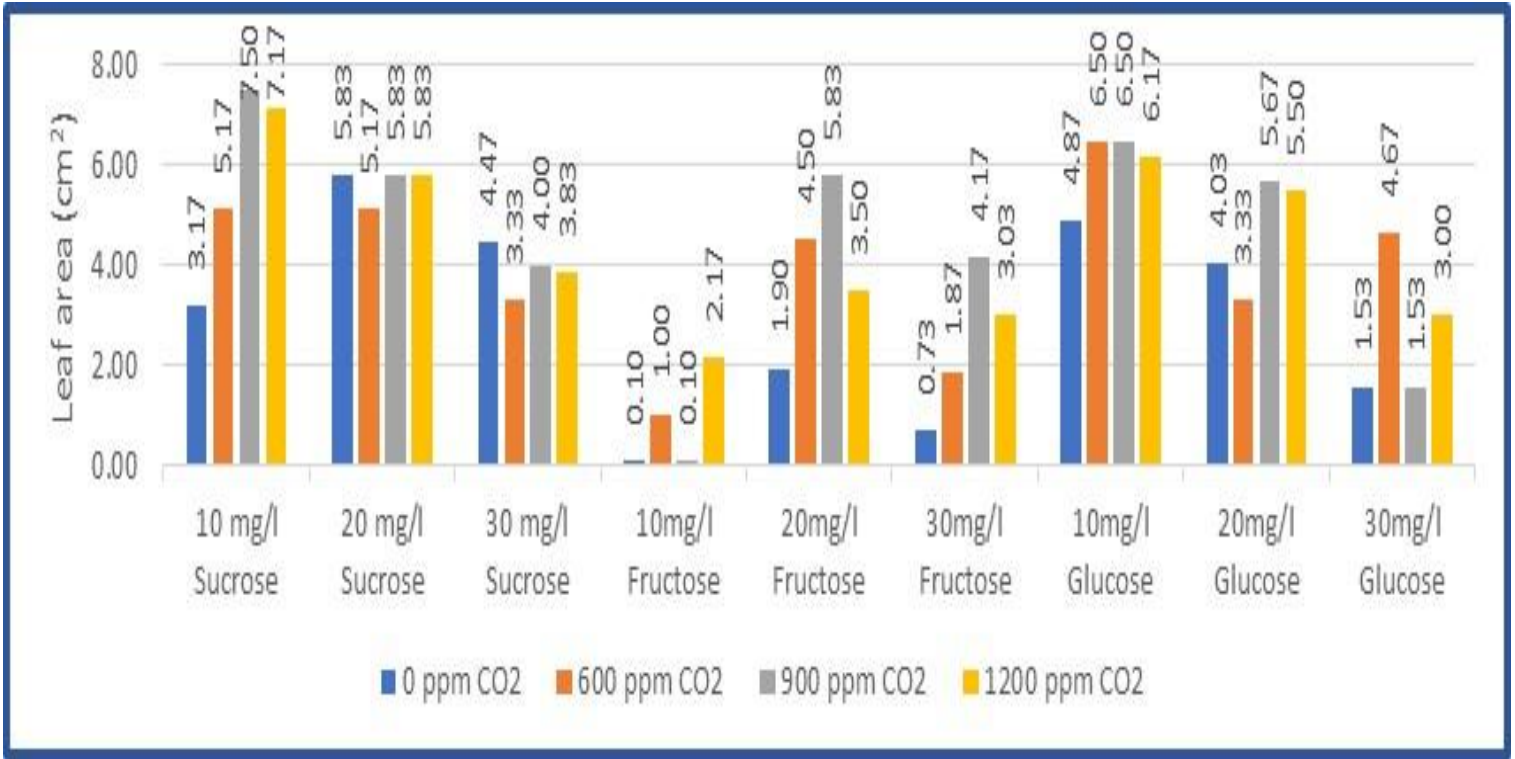

Fig.4 Effect of photomixotrophic and different concentrations of sucrose on plantlet growth parameters of banana cultivar Grande Naine during rooting stage

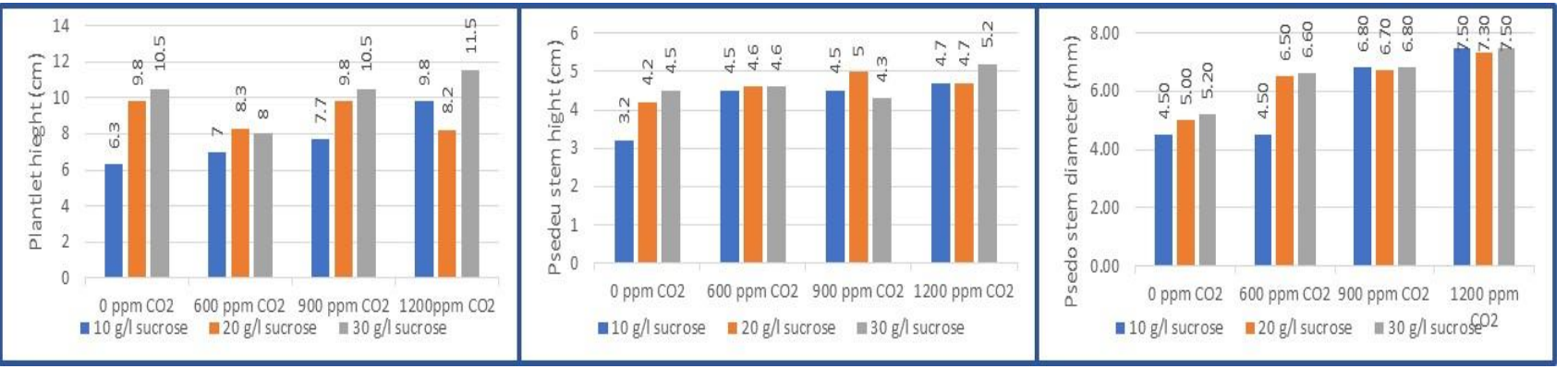

Photo.1 Preparing of $\mathrm{CO}_{2}$ enrichment culture vessels and caps of culture jars with cellulose nitrate membrane

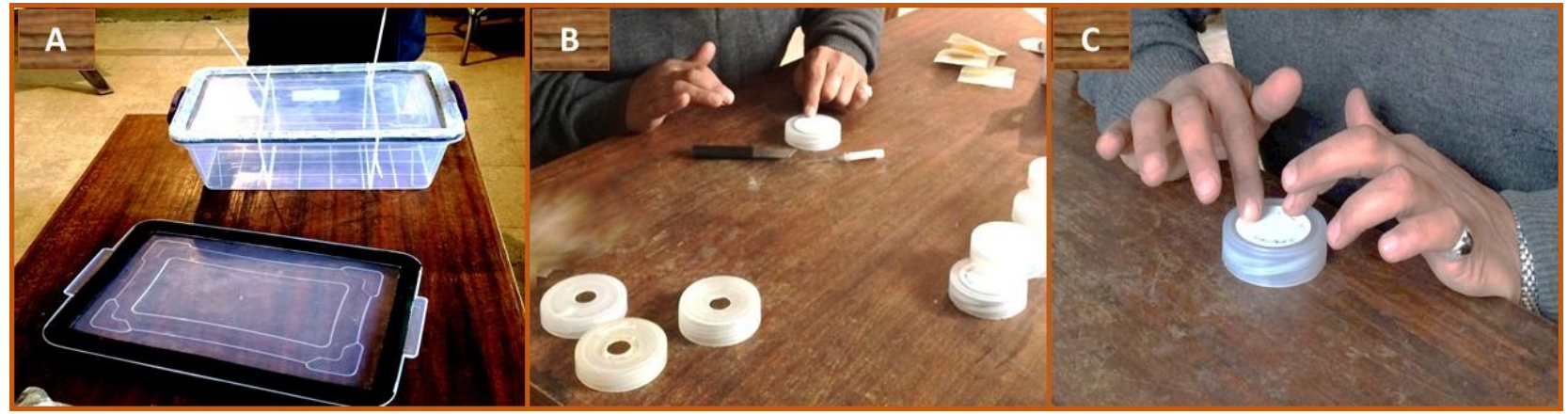

Where: A: Preparing of boxes B: Method of vessel modifying caps, C: Fixing of cellulose nitrate membrane on culture jars caps 
Photo.2 In vitro banana shoots growing on MS medium supplemented with 10, 20 and 30g/l sucrose under photomixotrophic technique at $1200 \mathrm{ppm} \mathrm{CO}_{2}$ and without $\mathrm{CO}_{2}$ in multiplication stage

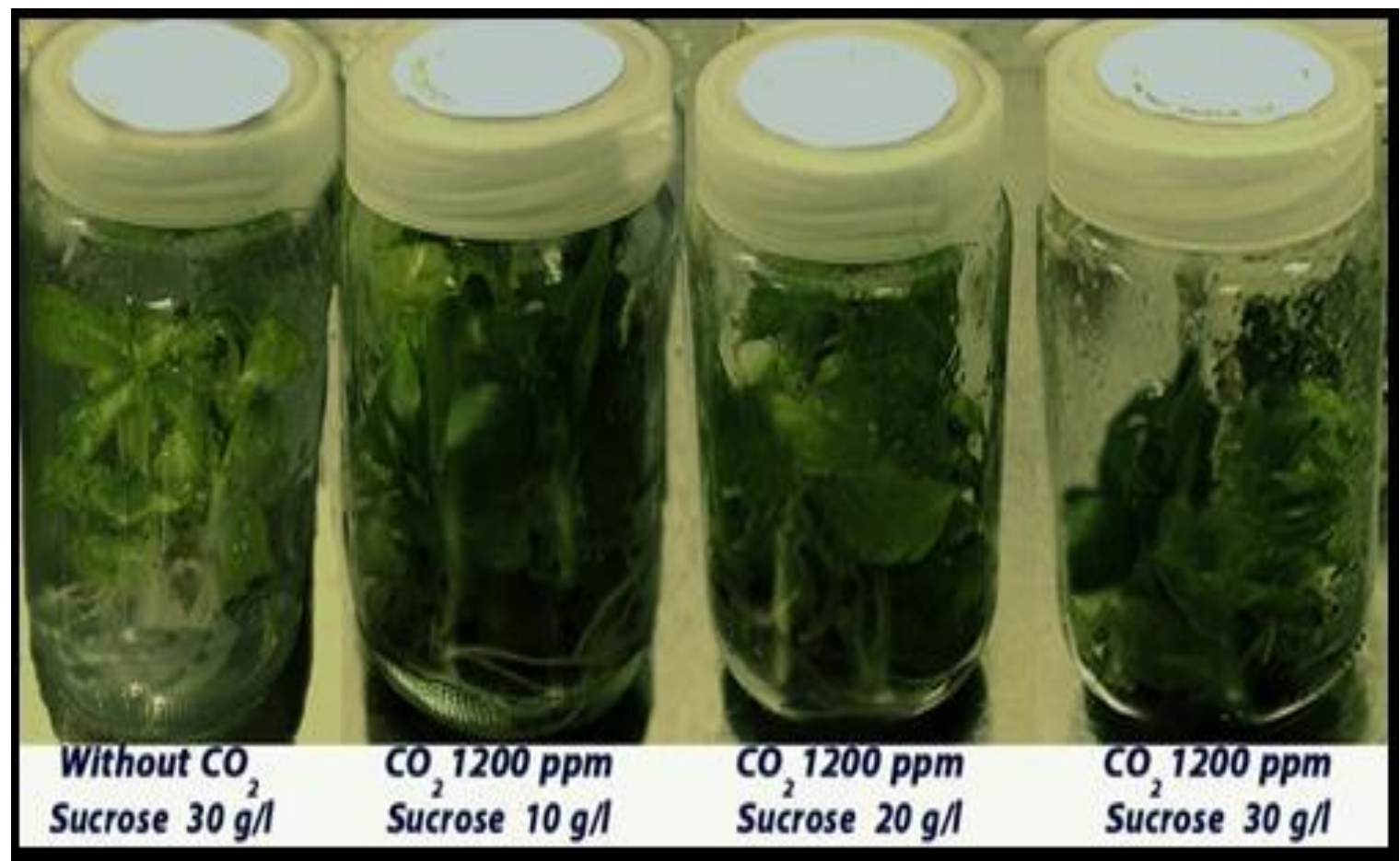

Photo.3 Effect of photomixotrophic and different concentrations of sucrose on growth and development of banana cultivar Grande Naine during rooting stage

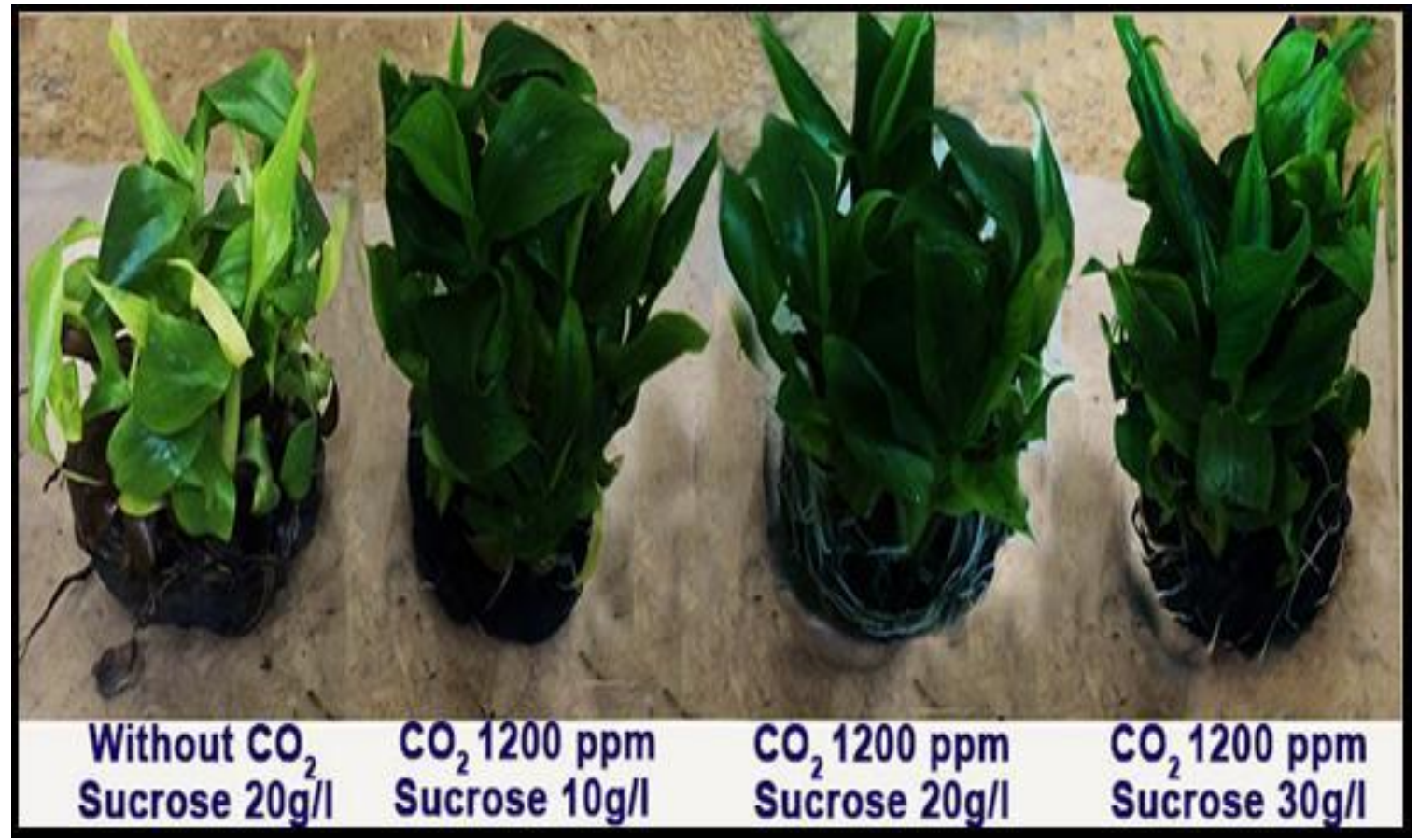


Photo.4 Effect of photomixotrophic in vitro on growth and development of banana cultivar Grande Naine after acclimatization stage

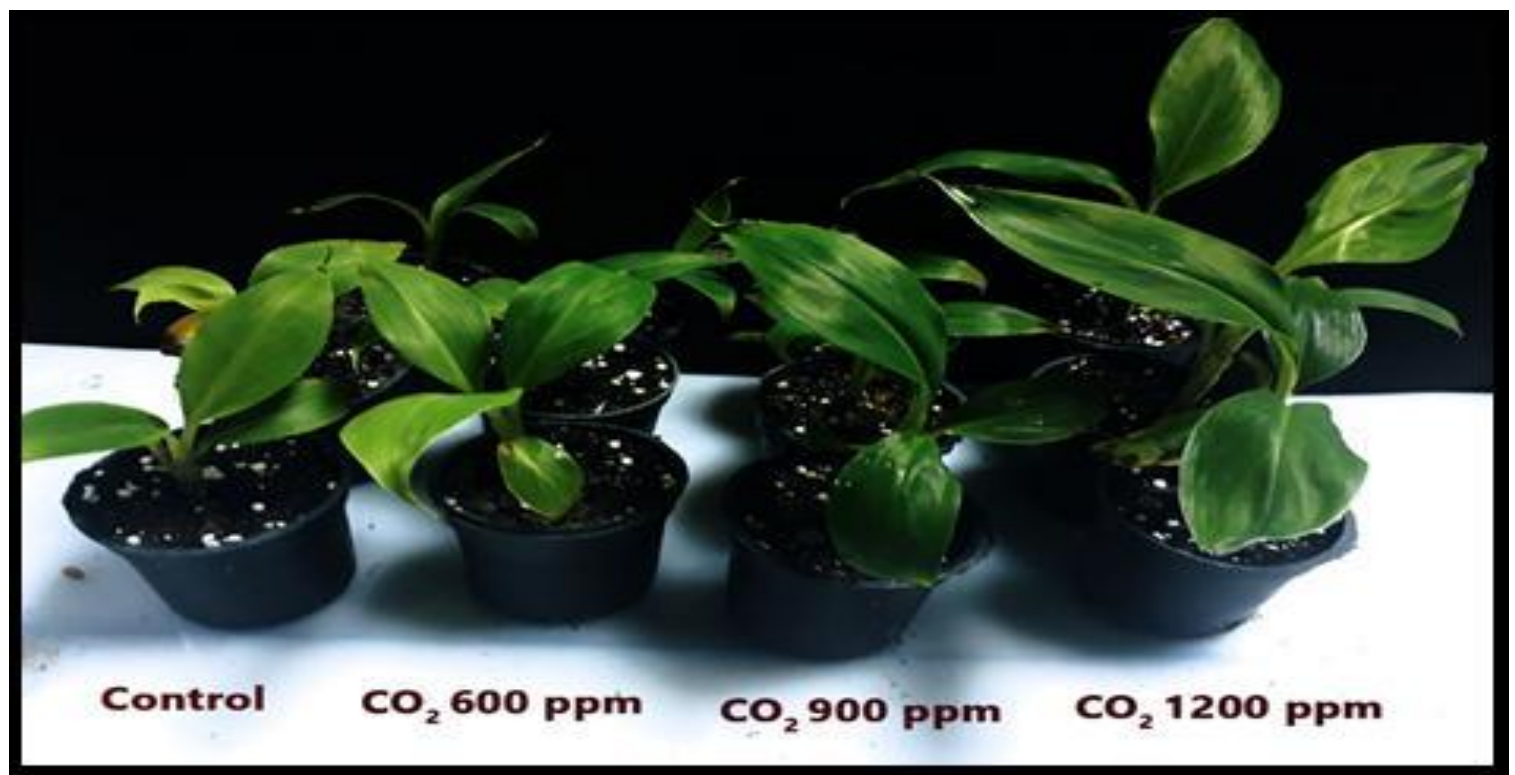

Plantlet weight was significantly enhanced with increasing sucrose concentrations (Table 4). Also, all $\mathrm{CO}_{2}$ enrichment concentrations enhanced plantlet weight and all $\mathrm{CO}_{2}$ enrichment concentrations cleared significantly priority on free- $\mathrm{CO}_{2}$ vessels. Interaction between sucrose concentrations and $\mathrm{CO}_{2}$ enrichment indicated that there were no significant differences between the following superior treatments, MS+30g/l sucrose in presence of 600ppm $\mathrm{CO}_{2}, \mathrm{MS}+20$ or $30 \mathrm{~g} / \mathrm{l}$ sucrose in presence of $900 \mathrm{ppm} \mathrm{CO}_{2}$ or $\mathrm{MS}+10,20$ 0r $30 \mathrm{~g} / \mathrm{l}$ sucrose in presence of $1200 \mathrm{ppm} \mathrm{CO}_{2}$. This mean that $\mathrm{CO} 2$ enrichment can enhance plantlet weight with decrease the sucrose concentrations in medium by $66.7 \%$ (10g/l sucrose).

Evaluation of photomixotrophic technique and different concentrations of sucrose as affecting banana plantlet parameters during acclimatization stage

Data in Table 5 and Photo 4 revealed that sucrose concentrations affected number and percentage of plantlets survival ranged from
90.9 to $95.5 \%$ with no significant difference among 10,20 or $30 \mathrm{~g} / \mathrm{l}$ sucrose. On the contrary, photomixotrophic technique significantly enhanced number of survival plantlets (percentage) compared with all treatments free of $\mathrm{CO}_{2}$ enrichment. Photomixotrophic in 1200ppm $\mathrm{CO}_{2}$ with $10 \mathrm{~g} / \mathrm{l}$ sucrose maximized the survival number/percent to $100 \%$. Anyway, photomixotrophic at 900 or $1200 \mathrm{ppm} \mathrm{CO}_{2}$ with all sucrose concentrations gave the highest survival number/percent with no significant difference among all tested treatments, which mean that presence of $\mathrm{CO}_{2}$ enrichment around the culture containers atmosphere may reduce the need of sucrose in culture medium to $1 \%$ instead of $3 \%$. This result led to augmented produced plantlets and configure them to tolerant the shock of acclimatization by enhancing photosynthesis, respiration and transpiration systems.

Photomixotrophic technique which includes enrichment of $\mathrm{CO}_{2}$ and different concentrations of sugar types affected banana growth parameters during multiplication, 
rooting and acclimatization stages. Using permeable membrane as a cover for the culture jars to allow gas exchange and increase $\mathrm{CO}_{2}$ concentrations in the inner atmosphere led to improve growth under that condition. In multiplication stage, plant growth parameters were affected by concentrations of carbohydrate sources; but the most effective source was sucrose. These results may attribute to sucrose permeability through cell membrane and gradually consumption where it saves a source of energy; which is needed as start point for plant cell metabolism. These results supported by (Petersen et al., 1999, Wang et al., 1999, Nguyen and Kozai, 2001, Morfeine, 2014 and Emara et al., 2017) who reported that sucrose is the most effective carbohydrate source for plant tissue culture as it is easy to be uptake. On the other hand, results disagree with Rolland et al., 2002, Amiard et al., 2005; Franck et al., 2006 and Jo et al., 2009 who stated that sucrose may suppress photosynthesis because sucrose saves sufficient energy which is needed to metabolic activities. In addition, sucrose increases the osmotic pressure of culture medium and make nutrient uptake more difficult.

Photomixotrophic technique enhanced growth parameters of banana during multiplication stage (shoot number, shoot length, leaves number/explant and leaf area when compared with others free of $\mathrm{CO}_{2}$ supplier. Anyway, most growth parameters were motivated at 900 and 1200ppm $\mathrm{CO}_{2}$. These results refer to the role of $\mathrm{CO}_{2}$ in enhancement plant metabolic activities i.e., photosynthesis, which affected all growth parameters. These results agree with Zobayed et al., 2004, Hassankhah et al., 2014, Teixeira da Silva, 2014, and Pérez et al., 2015 who stated that photomixotrophic produced healthy and welldeveloped plantlet. Results indicated that need of sucrose could be decreased in presence of $\mathrm{CO}_{2}$. All growth parameters possessed high values with low concentrations of sucrose in presence of 600 , 900 or $1200 \mathrm{ppm} \mathrm{CO}_{2}$. Number of shoots (13.33 shoots/explant), shoot length $(7.50 \mathrm{~cm})$, number of leaves/explant (43.0 leaves/explant) and leaf area $\left(7.50 \mathrm{~cm}^{2}\right)$ were obtained from low concentrations of sucrose ( 10 or $20 \mathrm{~g} / \mathrm{l}$ ) in presence of $\mathrm{CO}_{2}$ enrichment (photomixotrophic) (600, 900 or 1200ppm $\mathrm{CO}_{2}$ ), these results my attributed to the metabolic enhancement ability of $\mathrm{CO}_{2}$ which affected all growth parameters. These results came in line with Kozai and Iwanami, 1988, Seko and Nishimura, 1996, Nguyen, Q. T.; Kozai, T. 2001, Kozai and Kubota, 2005, Shin et al., 2013, Hassankhah et al., 2014, and Pérez et al., 2015 who stated that photomixotrophic promote growth parameters of several plants.

Analysis data of growth parameters during multiplication stage indicated the priority of sucrose as a source of carbohydrate when compared with either glucose or fructose, so, it was selected to be the source of carbohydrate during rooting stage. most concentrations of $\mathrm{CO}_{2}$ enrichment enhanced plantlet length, pseudostem length and diameter in combination with MS medium supplemented with 10,20 or $30 \mathrm{~g} / 1$ sucrose, indeed, the highest values resulted from MS medium supplemented with $30 \mathrm{~g} / \mathrm{l}$ sucrose in presence of $1200 \mathrm{ppm} \mathrm{CO}_{2}$. In addition, in acclimatization stage, photomixotrophic at 900 or $1200 \mathrm{ppm} \mathrm{CO}_{2}$ with all sucrose concentrations gave the highest survival number and percentage with no significant difference among all tested treatments, which mean that presence of $\mathrm{CO}_{2}$ enrichment around the culture containers atmosphere may reduce the need of sucrose in culture medium to $1 \%$ instead of $3 \%$ (the most used in tissue culture medium). This result led to augment the vigor of the produced plantlets and configure them to tolerate the shock of acclimatization by 
enhancing photosynthesis and adjusting respiration and transpiration systems through activation of stomata functions and wax synthesis. Results supported with Zobayed et al., 2004; Xiao et al., 2011; Hassankhah et al., 2014; Morfeine, 2014 and Pérez et al., 2015 who concluded that in vitro growth of many species of plant can be promoted by increasing the $\mathrm{CO}_{2}$ concentration and light intensity, which decreasing the relative humidity of the vessel and lead to activate stomata and wax formation. They added that photomixotrophic culture gave healthy plantlets with higher leaf dry weight and welldeveloped leaves.

Photomixotrophic is an adequate technique for micropropagation. It can reduce the need of carbohydrate which means that explant could begin photosynthesis efficiently and stomata could configure to do its job, in addition wax could be induced to be well formed. For all of previous reasons, plantlet well be able to be acclimatized easily with good performance and healthy shape. In addition, sucrose is the favor source of carbohydrate in photomixotrophic technique because it saves the need of carbohydrate gradually, easy permeable through cell membrane and saves the energy which needed to start metabolic activities.

\section{References}

Amiard V, Mueh KE, Demmig-Adams B, Ebbert V, Turgeon R, Adams WW III (2005). Anatomical and photosynthetic acclimation to light environment in species with differing mechanisms of phloem loading. Proc. Natl. Acad. Sci. USA. 102: 12968-12973.

Badr A, Angers P, Desjardins Y (2011). Metabolic profiling of photoautotrophic and photomixotrophic potato plantlets (Solanum tuberosum) provides new insights into acclimatization. Plant Cell Tiss. Organ Cult. 107:13-24.
Dahab AMA, IA Ibrahim, AMS Arafa, AA Nower (2000): Effect of in vitro and ex vitro light intensity and in vitro aeration on growth of some plants of aracease family during in vitro rooting and adaptation stages. Egyptian Journal of Agricultural Research.78 (5) 2011-2027.

Düring H, Harst M. 1996. Stomatal behaviour, photosynthesis and photorespiration of in vitro-grown grapevines: effects of light and $\mathrm{CO} 2$. Vitis 35, 163-167.

Emara H.E., E. M. Hamza and W. A. Fekry, 2017. In vitro propagation and microtuber formation of potato in relation to different concentrations of some growth regulators and sucrose. Middle East Journal of Agriculture Research, 6(4): 1029-1037.

Figueira A, Whipkey A, Janick J. 1991. Increased $\mathrm{CO} 2$ and light promote in vitro shoot growth and development of Theobroma cacao. Journal of the American Society of Horticultural Science 116, 585-589.

Fournioux JC, Bessis R. 1993. Use of carbon dioxide enrichment to obtain adult morphology of grapevine in vitro. Plant, Cell, Tissue, and Organ Culture 33, 5157.

Franck N, Vaast P, Génard M, Dauzat J (2006). Soluble sugars mediate sink feedback down-regulation of leaf photosynthesis in field-grown Coffea arabica. Tree Physiol. 26:517-525.

Hamza, E.M. 2013. Factors affecting synseeds formation and germination of banana cultivar Grande Naine. World Appl. Sci. J., 25 (10): 1390-1399

Hassankhah A., K. Vahdati, M. Lotfi, M. Mirmasoumi, J. Preece and M. $\mathrm{H}$. Assareh (2014). Effects of ventilation and sucrose concentrations on the growth and plantlet anatomy of micropropagated Persian walnut plants. International Journal of Horticultural Science and Technology, 1(2): 111-120.

Ibrahim I.A., M.I. Nasr, A.A. Hemeida andE.M. Hamza (2006). Banaa micropropagation and somaclonal variation via tissue culture. Ph.D. thesis in Plant 
Biotechnology Department, Genetic Engineering and Biotechnology Research Institute (GEBRI), Meufiya University.

Jo E-A, Kumar RT, Hahn E-J, Paek K-Y (2009). In vitro sucrose concentration affects growth and acclimatization of Alocasia amazonica plantlets. Plant Cell Tissue Organ Cult. 96:307-315.

Khan PSSV, Kozai T, Nguyen QT, Kubota C, Dhawan V (2002) Growth and net photosynthetic rates of Eucalyptus tereticornis Smith under photomixotrophic and various photoautotrophic micropropagation conditions. Plant Cell, Tissue and Organ Culture 71 (2), 141-146

Kirdmanee C, Kitaya Y, Kozai T. 1995. Effects of $\mathrm{CO} 2$ enrichment and supporting material in vitro on photoauto- trophic growth of Eucalyptus plantlets in vitro and ex vitro. In Vitro Cell Development Biology 31, 144-149.

Kozai T, Iwanami Y. 1988. Effect of CO 2 enrichment and sucrose concentration under high photon fluxes on plantlet growth of carnation (Dianthus caryophyllus L.) in tissue culture during preparation stage. Journal of the Japanese Society of Horticultural Science 57, 279288.

Kozai T, Koyama Y, Watanabe I. 1988a. Multiplication of potato plantlets in vitro with sugar-free medium under high photosynthetic photon flux. Acta Horticulturae 230, 121-127.

Kozai T, Kubota C, Watanabe I. 1988b. Effect of basal medium composition on the growth of carnation plantlets in auto- and mixo-trophic tissue culture. Acta Horticulturae 230, 159-166.

Kozai; T. and C. Kubota (2005). Concepts, definitions, ventilation methods, advantages and disadvantages. Chapter 3. Kozai et al., (eds.), Photoautotrophic (sugar-free medium) micropropagation as a new propagation and transplant production system, 19-30. (C) 2005 Springer. Printed in the Netherlands.
Morfeine, E. A. 2014. Effect of sucrose and glucose concentrations on micropropagation of Musa sp.cv. Grand Naine. Journal of Applied and Industrial Sciences, 2 (2): 58-62

Murashige T, Skoog F (1962). A revised medium for rapid growth and bioassays with tobacco tissue cultures. Physiol. Plant, 15: 473-497.

Nguyen, Q. T.; Kozai, T. 2001. Growth of in vitro banana (MUSA SPP.) shoots under photomixotrophic and photoautotrophic condition. In Vitro Cell. Dev. Biol.Plant 37:824-829.

Nguyen, Q.T., Hoang, T.M., Nguyen, H.N., 2010. Effects of sucrose concentration, ventilation rate and light intensity on the growth of country borage (Plectranthus amboinicus (Lour.) Spreng.) cultured photoautotrophically in nylon bags having ventilated membranes. In: Proceedings of National Conference on Plant Biotechnology for Southern Area, held in Hochiminh City in October 24-25, 2009. Science and Technology Publishing House, Hochiminh City, (in Vietnamese with English abstract), pp. 297-301.

Nguyen, Q.T., Kozai, T., Heo, J., Thai, D.X., 2001. Photoautotrophic growth response of in vitro coffee plantlets to ventilation methods and photosynthetic photon fluxes under carbon dioxide enriched condition. Plant Cell Tissue Org. Cult., 66: 217-225.

Pérez, L. P., Y. P. Montesinos, J. G. Olmedo, et al., (2015). Effects of different culture conditions (photoautotrophic, photomixotrophic) and the auxin indolebutyric acid on the in vitro acclimatization of papaya (Carica papaya L. var. Red Maradol) plants using zeolite as support. African Journal of Biotechnology. 14(35): 2622-2635.

Petersen, K. K., Hansen, J. and Krogstrup, P., 1999. Significance of different carbon sources and sterilization methods on callus induction and plant regeneration of Miscanthus x ogiformis Honda Giganteus'. Plant cell, tissue and organ culture, 58 (3): 189-197. 
Rolland F, Moore B, Sheen J (2002). Sugar sensing and signaling in plants. Plant Cell 14: 185-205.

Sallanon H, Dimon B, Carrier P, Chagvardieff P. 1995. Effect of CO2 concentration and irradiance on growth and photosynthesis of Juglans regia plantlets grown in vitro. Photosynthetica 31, 241-249.

SAS Institute, 2002. SAS ${ }^{\circledR}$ User's guide: Statistics. Version 9.0. SAS Institute, Cary, North Carolina, USA

Sekeli R, Abdullah JO, Namasivayam P, Muda P, Abu Bakar UM (2013). Better rooting procedure to enhance survival rate of field grown Malaysian Eksotika papaya transformed with 1-Aminocyclopropane1-carboxylic acid oxidase gene. ISRN Biotechnology 13: 1-10.

Seko Y, Kozai T. 1997. Effect of CO2 enrichment and sugarasparagus free medium on survival and growth of turfgrass regenerants grown in vitro. In: Goto E, Kurata K, Hayashi M, Sasa S, eds. Plant production in closed ecosystems. Dordrecht: Kluwer Academic Publishers, 600-605.

Seko Y, Nishimura M. 1996. Effect of CO2 and light on survival and growth of rice regenerants grown in vitro on sugar-free medium. Plant, Cell, Tissue, and Organ Culture 46, 257-264.

Shin K-S, Park S-Y, Paek K-Y (2013). Sugar metabolism, photosynthesis, and growth of in vitro plantlets of Doritaenopsis under controlled microenvironmental conditions. In vitro Cell. Dev. Biol. Plant 49: 445-454.
Steel, G.D. and J.H. Torrie (1980). Principles and procedures of statistics, Mc Grow Hill Boot-Col. New York.

Teixeira da Silva J.A., M. M. Hossain, M. Sharma, J. Dobránszki, J. C. Cardoso, and Z. Songjun, 2017. Acclimatization of in vitro-derived dendrobium. Horticultural Plant Journal, 3 (3): 110-124.

Teixeira da Silva JA (2014). Photoauto-, Photohetero-and Photomixotrophic in vitro propagation of papaya (Carica papaya L.) and response of seed and seedlings to light-emitting diodes. Thammasat Int. J. Sci. Technol. 19(1):5771.

Wang, H. L., Lee, P. D., Liu, L. F. \& Su, J. C., 1999. Effect of sorbitol induced osmotic stress on the changes of carbohydrate and free amino acid pools in sweet potato cell suspension cultures. Botanical Bulletin of Academia Sinica, 40 (7): 219-225.

Xiao, Y., Niu, G., Kozai, T., 2011. Development and application of photoautotrophic micropropagation systems. Plant Cell Tissue Org. Cult., 105: 149-158.

Zobayed, S.M.A., Afreen, F., Xiao, Y., Kozai, T., 2004. Recent advancement in research on photoautotrophic micropropagation using large culture vessels with forced ventilation. In Vitro Cell. Dev. Biol. Plant, 40: 450-458.

Zobayed, S.M.A., J. Armstrong, and W. Armstrong. 2001. Leaf Anatomy of in Vitro Tobacco and Cauliflower Plantlets as Affected by Different Types of Ventilation. Plant Sci., 161:537-548.

\section{How to cite this article:}

Emara, H.A., A.A. Nower, E.M. Hamza and El Shaib, F. 2018. Evaluation of Photomixotrophic Technique and Several Carbohydrate Sources as Affecting Banana Micropropagation. Int.J.Curr.Microbiol.App.Sci. 7(10): 788-804. doi: https://doi.org/10.20546/ijcmas.2018.710.088 